\title{
DA LAICIDADE DO ESTADO COMO FUNDAMENTO DA CIDADANIA IGUALITÁRIA: UMA LUTA HISTÓRICA NO CAMPO DA EDUCAÇÃO'
}

\author{
Roseli Fischmann ${ }^{2}$
}

\begin{abstract}
Resumo:
Partindo do dispositivo central na definição da laicidade do Estado, o Art. 19 da Constituição Federal de 1988, que proíbe relações de dependência ou aliança entre o Estado e as religiões, busca-se analisar as relações entre laicidade e garantia de igualdade para toda a cidadania, sem "distinções entre brasileiros ou preferências entre si", como estabelece o inciso III do mesmo artigo. Tomando os primórdios da República e seus documentos como marco dessa igualdade que não aceita distinções, preferências, privilégios, faz-se análise de dispositivos da Constituição de 1824, da Constituição de 1891, e da Constituição Federal de 1988. Evidenciase como a ordem monárquica é afeita à desigualdade, enquanto a ordem republicana a rejeita. O modo como a educação e a escola são concebidas em cada caso, é também analisado.
\end{abstract}

Palavras-chave: Laicidade do Estado. Cidadania igualitária. Escola pública laica.

\begin{abstract}
:
Proceeding from the legal text that defines the laicity of the State, the article 19 of the Federal Constitution of Brazil (1988) determines the impediment to the Federation, states or cities governments to establishing relations of dependency or alliance between the State and religions. This article seeks to analyze another part of the same Constitutional article, the one giving guarantee for all citizenship of equal treatment, without "distinctions between Brazilians or preferences among each other", the item III of that article. In fact, it is a commandment that was first stated in the early days of the Republic, one of the most important changes that occurred when Brazilian juridical order changed from the Constitution of the Empire of 1824, to the new Republic set of laws, starting in 1889. As much as the Monarchical order is close to inequality, the Republican order rejects it.
\end{abstract}

Keywords: Secularity of the State. Egalitarian citizenship. Secular public school.

\section{Introdução}

Para compreender a importância da laicidade na formação histórica do Estado brasileiro e sua inextrincável relação com a educação, especialmente a escola pública, assim como para identificar desafios e incompreensões que enfrenta, é preciso tomar como marco a proclamação

\footnotetext{
${ }^{1}$ A primeira versão deste trabalho foi aprovada e apresentada na $39^{\text {a }}$ Reunião Nacional da ANPEd, realizada na Universidade Federal Fluminense (UFF) - Campus Gragoatá, Niterói-RJ, de 20 a 24 de outubro de 2019, no Painel Temático "Laicidade do Estado e Educação sob Ataque: Intersecções e Resistências", do qual a autora participou também como coordenadora, painel que contou com apresentações dos professores doutores Fernando Seffner, da UFRGS, e Fernando de Araújo Penna, da UFF.

${ }^{2}$ PPGE/FEUSP, Pesquisadora PQ 1C/CNPq, roselif@usp.br
} 
da República, em 1889, bem como seus primeiros documentos legais, em 1890 e 1891, comparativamente à ordem jurídica anterior. Em outras palavras, a proclamação e implantação da República, no Brasil, é um marco para a compreensão da laicidade do Estado, sendo essa afirmação que será desenvolvida ao longo deste artigo.

O campo de estudos sobre laicidade do Estado teve grande impulso após os debates havidos antes e depois do Acordo Brasil - Santa Sé, instrumento jurídico também conhecido como concordata. A primeira notícia sobre as tratativas para o acordo foi publicada no jornal Folha de S. Paulo, em novembro de 2006, em artigo assinado por esta pesquisadora (FISCHMANN, 2006), resultando em grande mobilização de movimentos sociais, acadêmicos de diferentes áreas e diversos grupos religiosos, embora recebendo, preliminarmente, pouca atenção da imprensa (FISCHMANN, 2007-a).

Em um primeiro momento, houve um recuo do Governo Lula, de modo que não houve a assinatura que era prevista para a visita do Papa Bento XVI ao Brasil, quando da canonização de Frei Galvão, em maio de 2007, além de o Presidente Lula ter se comportado de modo a corresponder à expectativa que há em torno de quem jurou defender a Constituição (FISCHMANN, 2007-b).

Contudo, dezoito meses depois da negativa do Presidente Lula e dois anos depois do primeiro alerta na Folha de S. Paulo, em novembro de 2008, foi assinado no Vaticano o planejado Acordo, com a então aspirante à candidata acompanhando o Presidente Lula e sua esposa em visita ao Papa Bento XVI, como amplamente anunciado e reproduzido a seguir. (Imagem 1) 


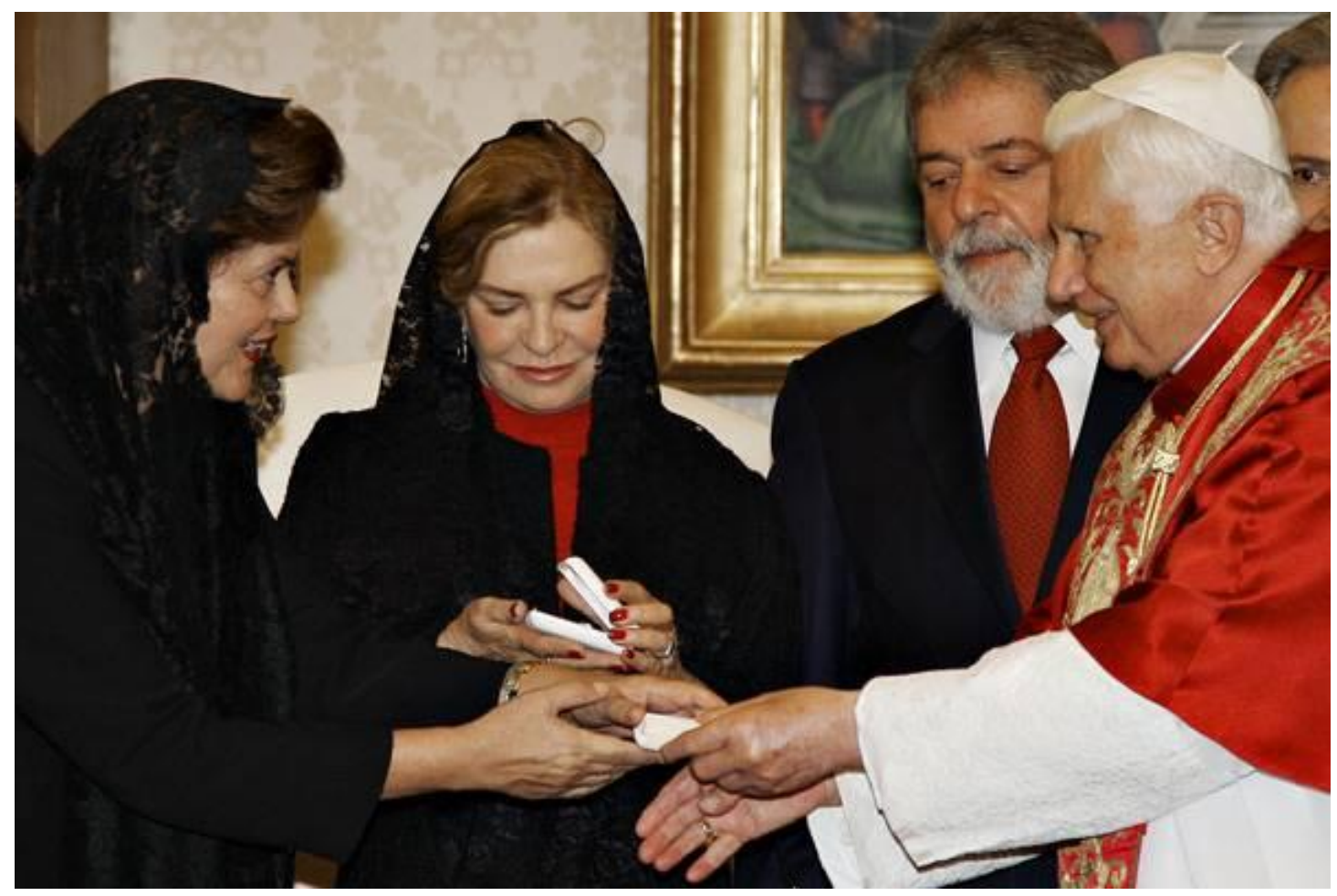

Legenda para a foto, do Portal G1, com crédito da foto:

"Da esq. para a dir, a ministra Dilma Roussef (Casa Civil), a primeira-dama, Marisa Letícia, e o presidente Lula, durante encontro com o Papa Bento XVI. Nesta quinta (13), entrevista publicada no jornal 'Corriere Della Serra' traz afirmação de Lula sobre a possível candidatura de Dilma à Presidência da República. 'Eu, na verdade, já tenho um nome em mente: o de Dilma Rousseff, ministra-chefe da Casa Civil do governo. Ainda não falei com ela, mas acredito que poderia ser uma boa candidata', afirmou. (Foto: Ricardo Stuckert/Presidência)". (PORTAL G1, 2008).

A assinatura do Acordo encontrou uma imprensa relativamente acomodada (FISCHMANN, 2008; DINES, 2008). Gerou, contudo, debates ardorosos, pois não seria fato consumado, do ponto de vista jurídico, até que o Congresso Nacional aprovasse o referido Acordo bilateral, conforme exige a Constituição. Com isso, a tramitação foi iniciada pela Mensagem no 134, de 2009, com Exposição de Motivos assinada pelo Secretário Geral do Ministério das Relações Exteriores ao Congresso Nacional, em fevereiro de 2009, encaminhando o Acordo para análise e aprovação.

Tratou-se de novo momento de grande mobilização social e acadêmica, previamente preparado pela bem sucedida mobilização de dois anos antes. Iniciado o debate pela Comissão de Relações Exteriores e Defesa Nacional, os deputados federais daquela Comissão convidaram pessoal e unicamente esta pesquisadora para comparecer à audiência pública (comparecimento 
que acabou por se repetir mais duas vezes) e oferecer esclarecimentos resultantes de sua pesquisa, conforme já relatado e analisado anteriormente (FISCHMANN, 2009).

Contudo, a trajetória desse debate tão acalorado, com diferentes participantes atuando por parte da sociedade civil (XAVIER et alii, 2009), trazendo pautas diferenciadas e diversas, não foi o suficiente para impedir a aprovação do Acordo, que foi introduzido na ordem legal nacional após tramitação na Câmara Federal e no Senado Federal, como Decreto n $^{\circ}$ 7.107, de 11 de fevereiro de 2010.

Nesse quadro, a relevância da laicidade do Estado ganha um valor adicional, como uma controvérsia constitucional incrustrada no coração do sentido do que é ser República, para o Brasil. No âmbito da pesquisa, em diversos campos, louvam o Art. $5^{\circ}$ da CF (1988), que determina:

Art. $5^{\circ}$ Todos são iguais perante a lei, sem distinção de qualquer natureza, garantindo-se aos brasileiros e aos estrangeiros residentes no País a inviolabilidade do direito à vida, à liberdade, à igualdade, à segurança e à propriedade, nos termos seguintes:

VI - é inviolável a liberdade de consciência e de crença, sendo assegurado o livre exercício dos cultos religiosos e garantida, na forma da lei, a proteção aos locais de culto e a suas liturgias;

(...)

Seguem-se 78 incisos, garantidores de direitos e deveres de cada cidadão/ã, considerados cláusulas pétreas, de aplicação imediata.

Sendo um dos mais destacados direitos fundamentais de cada cidadã e cada cidadão, não é, contudo, o único dispositivo a determinar a laicidade do Estado. É que, sendo parte do capítulo referente à organização do Estado, é crucial dar a devida atenção ao Art. 19 da CF (1988). Enquanto o Art. $5^{\circ}$ garante a cada cidadão e cidadã o direito à liberdade de consciência, de crença e de culto, o Art. 19 determina, para proteção mútua, da cidadania e do Estado, vedação aos entes administrativos de diferentes dependências do Estado, ou seja:

Art. 19. É vedado à União, aos Estados, ao Distrito Federal e aos Municípios: I - estabelecer cultos religiosos ou igrejas, subvencioná-los, embaraçar-lhes o funcionamento ou manter com eles ou seus representantes relações de dependência ou aliança, ressalvada, na forma da lei, a colaboração de interesse público;

II - recusar fé aos documentos públicos;

III - criar distinções entre brasileiros ou preferências entre si.

Em artigos científicos, quem menciona o citado Art. 19, vale-se, com frequência, exclusivamente de seu inciso I, deixando ao largo o inciso III, que merece atenção. É sobre o Art. 19, inciso III que é apresentada aqui uma análise preliminar, baseada em documentos primários, como importante dispositivo constitucional ligado historicamente à laicidade do 
Estado, em si, bem como enquanto base de uma educação pública, gratuita, laica, livre e igualitária, de qualidade, para todas e todos da cidadania.

Acima foi lembrado que a República é um marco para a compreensão da laicidade do Estado no Brasil. Como se apresenta, pois, esse marco? Como historicamente se funda o Art. 19? Por que aparece em um mesmo artigo um inciso voltado para a laicidade e um artigo voltado para reafirmar - porque o Art. $5^{\circ}$ já afirma, logo no início da CF (1988) - a igualdade de todos e todas, "sem distinções" ou "preferências"?

O que se dá, nesse caso, é que o Art. 19 volta-se para tratar de uma herança pesada para a democracia e para a cidadania, qual seja, como o País, após anexado ao domínio europeu, viveu o largo tempo monárquico de quase quatro séculos, primeiro sob o Reino de Portugal, como colônia, e, a seguir, sob o Império, após a Declaração de Independência, em que vigorou a plena união entre o Poder Monárquico (ou Estado) e a Igreja Católica Apostólica Romana.

\section{Princípios monárquicos}

A Constituição do Império, de 1824, outorgada por D. Pedro I, abre-se com um prólogo que é exortação religiosa direta, em maiúsculas: "EM NOME DA SANTÍSSIMA TRINDADE". Afirma, logo adiante, como seria ser o Brasil (na ortografia da época):

Art. 5. A Religião Catholica Apostolica Romana continuará a ser a Religião do Imperio. Todas as outras Religiões serão permitidas com seu culto domestico, ou particular em casas para isso destinadas, sem fórma alguma exterior do Templo.

Se mais não houvesse, a afirmação de uma religião oficial única, restringia e constrangia os que tivessem outra fé ou culto, a exercê-lo em "casas sem forma alguma exterior" de templo. Era um "avanço", comparando ao que era vivido no período do Brasil Colônia, mas longe de representar liberdade de culto. A normatização especificou o entendimento para informar que os cultos deveriam se dar a portas fechadas, sem emissão sonora indicativa de culto, assim como impedia quem professasse outra fé ou religião de pronunciar em público essa condição. A respeito desse tema, por exemplo, afirma Wachholz (2009, p. 118):

Desta forma, ainda que em seu artigo 179 , parágrafo $5^{\circ}$, a Constituição rezasse que "ninguém pode ser perseguido por motivo de religião, uma vez que respeita a do Estado, e não ofenda a moral pública" (CONSTITUIÇÕES DO BRASIL, 1958, p. 12)1, não oferecia condições jurídicas iguais aos protestantes. Impunham-se aos protestantes restrições aos locais de culto, a saber, que este deveria ser fechado, portanto, não exercido publica- mente, e em casas sem aparência exterior de templo, o que significava, normalmente, que os templos não podiam ter torres e sinos.

Ressalte-se que toda monarquia tem vinculação religiosa, porque o argumento religioso, de ser supostamente vontade e decisão divina a origem para a distinção e discriminação que 
nesse regime de governo se faz entre "nobreza" e "plebe", além do que se passa no interior da própria nobreza, entre os que se encontram ou não na linha sucessória, quem detém um título ou outro, e da constituição de certo tipo de aristocracia, que igualmente se percebe como investida de um tipo de "direito a ter privilégios" (conclusão desta pesquisa, derivado de Elias (1983/2001/2012). Ou seja, o regime monárquico é estabelecido com base na desigualdade fundamental entre pessoas, não sendo todas igualmente constituintes do Estado.

A sociedade de corte, estudada por Elias, organiza as relações sociais e altera as relações intersubjetivas, mudando mesmo psiquês, como existiam antes da constituição da sociedade de corte entre os séculos XII e XVIII, como analisa Roger Chartier (1983/2001/2012) no longo prefácio que faz ao livro de Elias. Pode-se afirmar que a mera existência da monarquia já implica a desigualdade entre os coabitantes de um mesmo país, por isso o elemento religioso ganha tanta força ao ser invocado na Constituição, amparando a figura do Imperador, que se oferece como sagrado, pois coroado por vontade divina, em sua própria definição na Constituição outorgada.

Sendo tema para outros trabalhos, a literatura registra que há, durante o Império no Brasil, seja o primeiro, seja o segundo, grande diferença entre a nobreza existente em Portugal e a pífia que se autoproclamou independente no Brasil, embora associada à nobreza de Portugal. No Brasil destacou-se uma aristocracia, formada por bacharéis, militares de alta patente, grandes proprietários rurais, que se permitiam viver como elite aristocrática, assegurando-se o seu próprio "direito a privilégios".

O ponto central, assim, é que a escolha de uma determinada religião para ser "a Religião do Império", predispõe os papeis na sociedade. Portanto, ainda que livres para ter sua crença, seu culto, se não for o oficial, deverá ser exclusivamente a portas fechadas.

As repercussões de haver uma única religião não apenas oficial, mas completamente associada ao Estado (fosse essa religião qual fosse), vão além do que se viveu no Império, com a marca da forma de templo para as práticas e cultos permanecendo após a proclamação da República, chegando aos dias atuais. Assim é possível constatar:

Esta presença marcante e articulada pode ser vista ao se visitar as cidades de Ouro Preto e Mariana. Por meio da arquitetura, a presença de muitos templos aponta para uma cultura católica enraizada na vida da população. Outro mecanismo de análise é o Censo 2010 do Instituto Brasileiro de Geografia e Estatística (IBGE). Enquanto a predominância de cristãos soma 86,8\% da população (64,6\% católicos e 22,2\% evangélicos) no Brasil, nas cidades de Ouro Preto e Mariana, o percentual é maior e chega a 94\% (TABELA 1) em cada uma delas. Os outros $6 \%$ estão fatiados entre ateus e agnósticos, em torno de 4\%; os espíritas, $0,7 \%$ da população de Mariana e 1,3\% da de Ouro Preto; os pertencentes à umbanda e ao candomblé, somam, juntos, $0,02 \%$ em 
Mariana e 0,05\%, na cidade vizinha. (SANTOS; TORRES; FONSECA, 2016, p. 127-128).

Observe-se a concentração maciça de ser quase $100 \%$ da população católica, acima da porcentagem nacional. Indicam os autores, também, como sendo hegemônica a presença católica e assim sua visibilidade, como chega a invisibilizar os demais credos:

Diante desse cenário no campo religioso, as cidades são conhecidas pelas suas igrejas que demarcam presença na arquitetura, obscurecendo até mesmo a percepção no espaço urbano de outros templos religiosos. (...)

Em Mariana, 22 bens foram tombados e mais da metade (15) está relacionada à Igreja Católica Apostólica Romana, sendo três capelas e 11 igrejas e um Seminário. Em Ouro Preto, o número de inscritos no Livro do Tombo é ainda maior. Dos 47 bens registrados, quase a metade (22) são templos religiosos; nove capelas e 13 igrejas.

É meritória a análise, nesse artigo, que permite trazer a noção de invisibilidade - e nesse caso, duradoura - aplicada à diversidade religiosa, por meio das proibições constitucionais relativas à arquitetura, ao longo do período imperial, proibições retiradas há 130 anos. Da mesma forma, indicam o que se passa na relação entre religião e presença no patrimônio histórico, no qual outros grupos, distintos da Igreja Católica, também encontram-se invisibilizados no presente. A já citada Concordata com a Santa Sé, a propósito, traz em seu texto:

Art. $6^{\circ}$. As Altas Partes reconhecem que o patrimônio histórico, artístico e cultural da Igreja Católica, assim como os documentos custodiados nos seus arquivos e bibliotecas, constituem parte relevante do patrimônio cultural brasileiro, e continuarão a cooperar para salvaguardar, valorizar e promover a fruição dos bens, móveis e imóveis, de propriedade da Igreja Católica ou de outras pessoas jurídicas eclesiásticas, que sejam considerados pelo Brasil como parte de seu patrimônio cultural e artístico.

$\S 1^{\circ}$. A República Federativa do Brasil, em atenção ao princípio da cooperação, reconhece que a finalidade própria dos bens eclesiásticos mencionados no caput deste artigo deve ser salvaguardada pelo ordenamento jurídico brasileiro, sem prejuízo de outras finalidades que possam surgir da sua natureza cultural.

$\S 2^{\circ}$. A Igreja Católica, ciente do valor do seu patrimônio cultural, compromete-se a facilitar o acesso a ele para todos os que o queiram conhecer e estudar, salvaguardadas as suas finalidades religiosas e as exigências de sua proteção e da tutela dos arquivos. (BRASIL, 2010).

A longa citação fez-se necessária porque são textos que indicam impactos jurídicos, nos dias atuais, da hegemonia religiosa no que se refere a patrimônios históricos, incluindo compromissos ao Estado brasileiro em termos de salvaguarda, com possíveis impactos orçamentários também.

Caberia, assim, indagar, para futuras pesquisas, quais seriam, ainda atualmente, as repercussões advindas desse tipo de preferência estabelecida pela Constituição do Império, que repercute atualmente quanto à invisibilidade da diversidade religiosa, no que se refere ao tratamento igualitário entre brasileiros/as? 
Indo além, porém, das configurações do sagrado no espaço público, a repercussão se volta reflexivamente para o próprio modo de constituir o Estado, conforme os princípios imperiais.

Tanto é assim, que a Constituição de 1824 definia quem era cidadão (Art. $6^{\circ}$ a $8^{\circ}$ ), no sentido de haver exigências a preencher para tanto - nem cabendo a preocupação com cidadãs, por exemplo. Mais ainda, nem todos os cidadãos podiam votar nas "Assembléas Parochiaes" (Art. 92 e 93), sendo excluídos como eleitores, por exemplo: “os criados de servir”, com algumas exceções, como "os administradores das fazendas ruraes, e fabricas"; "os que não tiverem de renda liquida annual cem mil réis por bens de raiz, industria, commercio, ou Empregos".

Em sequência, quem não podia votar na “Assembléa Parochial”, o nível mais básico da estruturação do Estado Imperial no Brasil, tendo a paróquia católica como sua base, não podia ser eleitor em nenhuma outra eleição (Art.94), menos ainda candidatar-se. Mas se tivesse conseguido qualificar-se para ser eleitor, ainda não poderia se candidatar a cargo eletivo, se fosse enquadrado em algumas categorias no Art. 95, a saber:

I. Os que não tiverem quatrocentos mil réis de renda liquida, na fórma dos Arts. 92 e 94.

II. Os Estrangeiros naturalisados.

III. Os que não professarem a Religião do Estado.

Portanto, mesmo que superados todos os demais obstáculos para exercício da cidadania, que não eram poucos nem pequenos, professar a Religião do Estado era a condição sine qua non para ser investido do poder de ser candidato e de votar nas eleições. Com isso, fica demonstrado que o regime de desigualdade política entre cidadãos e mesmo para a simples qualificação como cidadão, que era vigente no Império, tinha como seu fundamento primeiro a união entre Estado e Religião Oficial.

É indispensável incluir nas demonstrações dessa desigualdade cidadã estabelecida constitucionalmente naquele regime, a existência da escravidão e o tratamento de seres humanos escravizados como se objetos fossem, já que eram registrados em cartório, como se faz com imóveis e outras propriedades, parte de um comércio indigno e desumano que a todos era livre, sendo a única exigência dispor de numerário suficiente para tanto.

A manutenção, pelo Imperador outorgante da Constituição de 1824, das leis que vinham desde as Ordenações Filipinas é comprovativa de como a ordem colonial não se rompia com a Declaração de Independência, no tocante à dignidade humana.

Adicionalmente, a união oficial com a religião representa uma porta aberta ao absolutismo como modo de governar, em especial por considerar-se o monarca como escolhido 
por aquele que é sua divindade, a mesma que o escolheu para reinar sobre todos os demais, conforme texto constitucional em diversos dispositivos.

Assim, ainda que de modo introdutório, o que se percebe é que o marco que a implantação da República viria a representar, ainda que redigida de diferentes maneiras por entre 100 anos de diferentes Cartas constitucionais, vincula-se à proibição imposta aos entes do Estado - União, Distrito Federal, Estados e Municípios -, de "criar distinções entre brasileiros ou preferências entre si”. Mesmo sendo sabido que a profunda desigualdade econômica e social no Brasil é um fato, que mesmo inaceitável, não deixa de ser um fato - mas não é a Constituição Federal que a permite, podendo mesmo ser utilizada para coibir semelhante indigna desigualdade.

\section{Princípios republicanos e educação}

A proclamação da República deu-se em meio a conflitos, que já se anunciavam e ocorriam antes daquele 15 de novembro de 1889. Uma série de decretos promoveram a complexa transição de regimes que se fez então, no advento da República.

Um dos decretos mais fundamentais em termos dos princípios republicanos foi $\mathrm{o}$ Decreto 119-A, de 7 de janeiro de 1890, anterior à promulgação daquela que seria a primeira Constituição republicana do Brasil. Trata-se do decreto que determinou a separação entre o Estado brasileiro e as religiões, o que, de imediato, representou a separação entre o Estado e a Igreja Católica.

A ementa do Decreto 119-A esclarece estar voltado para um dos pontos mais essenciais dos princípios democráticos: "Prohibe a intervenção da autoridade federal e dos Estados federados em matéria religiosa, consagra a plena liberdade de cultos, extingue o padroado e estabelece outras providências". (BRASIL, 1890).

Ou seja, partindo do Estado republicano, o Decreto 119-A profere seu impedimento em termos de intervenção nas religiões, que passam a ter igualdade de personalidade jurídica, e que, como contraparte, não podem interferir no Estado. Mais ainda, removido o Imperador governante que era tido como representante da divindade, e encerrado o antes mencionado ciclo do "direito a privilégios" garantidos àqueles que coparticipavam da religião única, dispondo de títulos nobiliárquicos originados na suposta origem divina das decisões do Príncipe, finalmente é vedado ao Estado tratar cidadãos do País de modo desigual, como permanece ainda no Art. 19 da CF (1988), como tratado na introdução, nos seguintes termos:

Art. $1^{\circ} E^{\prime}$ prohibido á autoridade federal, assim como à dos Estados federados, expedir leis, regulamentos, ou actos administrativos, estabelecendo alguma religião, ou vedando-a, e crear differenças entre os habitantes do paiz, ou nos 
serviços sustentados à custa do orçamento, por motivo de crenças, ou opiniões philosophicas ou religiosas.(BRASIL, 1890).

Percebe-se, ainda, que o texto do decreto procura expandir seu efeito para opiniões filosóficas também, não apenas religiosas, o que indica particular cuidado com a liberdade de consciência e de crença, não apenas de culto. Busca-se atualizar, então, o "direito a ter direitos", como ensinado por Hannah Arendt (FISCHMANN, 2009-c), e não mais privilégios.

Há no Decreto 119-A a determinação de legislar sobre religião e crenças em geral não apenas na defesa de cada indivíduo "habitante do paiz", como também sobre as coletividades e instituições religiosas, nos seguintes termos:

Art. $3^{\circ} \mathrm{A}$ liberdade aqui instituida abrange não só os individuos nos actos individuaes, sinão tambem as igrejas, associações e institutos em que se acharem agremiados; cabendo a todos o pleno direito de se constituirem e viverem collectivamente, segundo o seu credo e a sua disciplina, sem intervenção do poder público.

Ainda, há o estabelecimento claro de que o Estado não mais seria responsável pela manutenção dos bens da Igreja Católica, o que ocorria no Império por sua associação mútua, extinguindo o Padroado ${ }^{i}$, ao mesmo tempo que se preocupou em garantir os bens até então obtidos pelas diferentes instituições e associações religiosas, como reconhecidas propriedades das mesmas:

Art. $4^{\circ}$ Fica extincto o padroado com todas as suas intituições, recursos e prerogativas.

Art. $5^{\circ}$ A todas as igrejas e confissões religiosas se reconhece a personalidade juridica, para adquirirem bens e os administrarem, sob os limites postos pelas leis concernentes à propriedade de mão-morta, mantendo-se a cada uma o dominio de seu haveres actuaes, bem como dos seus edificios de culto.

Apresentada a situação da separação entre o Estado e todas as religiões, após 389 anos de total identidade entre a ordem monárquica e a Igreja Católica, não se tratou de processo simples nem rápido, com repercussões ainda em andamento, como se percebe no caso da Concordata Brasil - Santa Sé.

Como parte do movimento republicano, em fins do século XIX, há mobilização de educadores e daqueles que atualmente seriam chamadas lideranças sociais, em termos de defender a escola pública para que pudesse ser laica. É interessante observar, nesse sentido, que, ainda antes da Constituição de 1891, a primeira Carta republicana, o Decreto $\mathrm{n}^{\circ}$ 981, de 8 de novembro de 1890, entre outras medidas afeitas ao então recém-criado Ministério da Instrução, Correios e Telégrafos:

Art. $2^{\circ} \mathrm{A}$ instrucção primaria, livre, gratuita e leiga, será dada no Districto Federal em escolas públicas de duas categorias:

$1^{\mathrm{a}}$ escolas primarias do $1^{\circ}$ gráo;

$2^{\mathrm{a}}$ escolas primarias do $2^{\mathrm{a}}$ gráo. 
$\S 1^{\circ}$ As escolas do $1^{\circ}$ gráo admittirão alumnós de 7 a 13 annos de idade, e as do $2^{\circ}$ gráo, de 13 a 15 annos. Umas e outras serão distinctas para cada sexo, porém meninos até 8 annos poderão frequentar as escolas do $1^{\circ}$ gráo do sexo feminino.

A afirmação de uma escola pública voltada para a instrução primária livre, gratuita e leiga (na terminologia de então), e ainda que restrita ao Distrito Federal, indica a preocupação em marcar a instauração do Estado laico e a separação total, promovida então pela República, entre o Estado e as religiões.

Por isso uma escola "leiga" era considerada como fundamental para a consolidação da República. Parte da argumentação era devida ao positivismo que se disseminou no Brasil e de modo especial entre os militares que estiveram à frente do movimento republicano, incluindo, aí também, associações desse positivismo ao cientificismo então bastante forte, que chegava da Europa ao País ${ }^{i i}$. Observe-se, ainda, a presença de escolas para meninas, o que no Império era exceção para meninas órfãs, e a então original elaboração de que meninos até 8 anos poderiam fazer acontecer o que na década dos 20 do século XX era chamada de coeducação, ou seja, meninos e meninas estudando juntos nas mesmas escolas.

Como a primeira afirmação republicana é essa para as escolas públicas, assim tem seguido a luta desde então. Associações de educadores, ao longo do século XX, marcaram presença defendendo a escola pública, gratuita e laica, acrescentando, nas últimas décadas, o adjetivo "de qualidade". No contexto do atual (des)governo federal, é evidente que urge voltar a incluir o adjetivo "livre", que lá estava, em 1890, para a então recém-nascida escola republicana.

Quem forma, historicamente, esses grupos de defesa da escola pública laica? Como tem se configurado essa luta?

Associações de classe, que antes de 1988 não podiam ser consideradas como sindicato ao reunir servidores públicos, associações científicas, movimentos populares, grupos de professores e professoras universitárias formados especificamente em torno da causa da escola pública laica.

Após a promulgação da Constituição Federal de 1946, tendo como mote a elaboração daquela que seria a primeira Lei de Diretrizes e Bases da Educação Nacional, ao longo dos anos 1950, a Campanha em Defesa da Escola Pública, que mobilizou as jovens universidades brasileiras em movimento que se espalhou por todos os rincões do País, para defender a escola pública e sua expansão para todas e todos (BARROS, 1960). São nomes como Anísio Teixeira 
e Florestan Fernandes que lá estão. É nessa luta que vem Angicos, de Paulo Freire (Beisiegel, C.R., 1983).

No contexto da redemocratização do Brasil na primeira metade dos anos 1980, foi decisiva a criação do Fórum Nacional em Defesa da Escola Pública, criado por diversas entidades, associações e instituições, fortalecido por fóruns estaduais, voltados para a elaboração e promulgação do que viria a ser a Constituição Cidadã, de 1988. Continuaram, a seguir, os trabalhos do Fórum Nacional e fóruns estaduais em direção tanto à elaboração das Constituições Estaduais, quanto à elaboração de uma nova Lei de Diretrizes e Bases da Educação Nacional, para regulamentar os dispositivos da Constituição Federal de 1988, que veio a ser a Lei $n^{\circ}$ 9394/96 ${ }^{\text {iii }}$.

A expansão das redes públicas de ensino, ligadas a diferentes instâncias administrativas - federal, estadual e municipal -, ampliou a oferta de oportunidades escolares à população brasileira, ao mesmo tempo que repetidas crises econômicas devolveram as camadas médias, antes vinculadas a escolas particulares de diferentes tipos e qualidade diversa, à escola pública.

Esse fortalecimento das escolas públicas, ocorre de modo alinhado e aliado a intensas e necessárias mudanças no quadro legal, cultural e social, no que se refere a: direitos das mulheres; direitos sexuais e reprodutivos; reconhecimento do valor da diversidade em geral, bem como da pluralidade cultural; fortalecimento dos movimentos contra o racismo; fortalecimento das exigências de inclusão em todos os ambientes, e em especial nas escolas; novas configurações familiares (onde sequer divórcio havia até 1977), incluindo também a condenação à homofobia e à transfobia; protagonismo de grupos sociais organizados, das antes chamadas minorias, com protagonismo também para além das organizações; plena visibilização das diversidades, dos gêneros e, com a popularização das redes sociais, a polifonia dessas vozes povoando o cotidiano da população em geral.

Tanto pautas identitárias, como acima mencionado, como aquelas voltadas para a compreensão dos compromissos que se precisa assumir e praticar em termos intergeracionais, seja no campo do meio ambiente e da paz, seja na adoção do antirracismo como norte de atuação, além de outras, que se renovam e se repõe a cada momento, como fruto da dinâmica social, destacam mais fortemente como os ideais republicanos ligados ao tratamento igualitário entre todos os brasileiros e brasileiras, colocam-se como programas e desafios para a educação pública, em todos os seus níveis, a que é preciso dar atenção e encontrar caminhos, a serem construídos coletivamente, sem dúvida. 


\section{Considerações finais}

Por ocasião dos debates em torno do Acordo Brasil - Santa Sé, especialmente em 2009, os grupos evangélicos (como são genericamente chamados, de modo impróprio pela diversidade aí incluída como se fosse homogênea e única, mas aqui utilizado para espelhar o debate público), em sua maioria, participaram ativamente da defesa do Estado laico. Houve um grupo, é verdade, que se posicionou reivindicando uma "Lei Geral das Religiões", afirmando que "se 'eles' (os católicos) têm (privilégios), nós também queremos" (FISCHMANN, 2009).

O Estado laico, republicano, tem relação direta, como mencionado, com o direito a ter direitos, igual tratamento para todas e todos. Entre outros equívocos, o Brasil vive, nesse momento, a situação de um Presidente que afirma que nomeará para o Supremo Tribunal Federal alguém que seja "terrivelmente evangélico", expressando sua disposição de violar o princípio de garantir igual tratamento a todas e todos, sem privilégio ou distinção. Não por ter escolhido que seja alguém "evangélico" a ser priorizado e valorizado por sobre os demais, mas por definir com base em uma escolha religiosa quem deverá ocupar posição tão relevante no sistema jurídico nacional.

Da mesma forma, em meio à pandemia de COVID-19, o mesmo Presidente decidiu passar por cima das recomendações de sanitaristas, infectologistas, epidemiologistas, para definir a possibilidade de abertura de igrejas e templos em meio a quarentena, como "atividades essenciais", para pacificar aliados religiosos que o pressionavam. Nesse caso, o suposto privilégio, aliás, seria perda e exposição ao sars-cov-2, de grande parte da população cuja fé as conduz a aderir a determinações, não apenas religiosas, de seus líderes religiosos. Ou seja, sob a capa da proteção a um grupo, esconde-se um mau trato, que poderia custar a vida a essas cidadãs e cidadãos.

A escola ser atacada e serem invocados projetos como Escola sem Partido. O ataque constante, frequentemente envolvendo discurso de ódio dirigido ao longo processo histórico de a inserção de questões sexuais, de gênero e de direitos reprodutivos nos diferentes níveis da escola, indicam que o momento é escorregadio, de abandono de ideais republicanos duramente conquistados como prática cotidiana nas escolas.

Portanto, ao lado do indispensável debate sobre a impropriedade do ensino religioso nas escolas públicas, ao tratar de educação e laicidade do Estado, é de grande relevância trabalhar não apenas com o inciso I do Art. 19 da Constituição Federal de 1988, mas também com o inciso III. 
Este trabalho procurou oferecer uma visão preliminar dessa relevância, amparando-se na transição histórica entre a Monarquia e a República no Brasil. Fica, pois, como um convite à reflexão e ao aprofundamento dessa vertente.

\section{Referências bibliográficas}

BARROS, R. S. M. (Org). Diretrizes e bases da educação nacional. São Paulo: Pioneira, 1960. BRASIL. CÂMARA DOS DEPUTADOS. Decreto $n^{\circ}$ 981, de 8 de Novembro de 1890 Publicação original. Approva o Regulamento da Instrucção Primaria e Secundaria do Districto Federal. Disponível em: https://www2.camara.leg.br/legin/fed/decret/1824-1899/decreto-9818-novembro-1890-515376-publicacaooriginal-1-pe.html . Acesso em: 03 jun. 2020.

BRASIL. PRESIDÊNCIA DA REPÚBLICA. Lei $n^{\circ}$ 9.394, de 20 de dezembro de 1996. (Vide Lei $\mathrm{n}^{\circ}$ 12.061, de 2009) Estabelece as diretrizes e bases da educação nacional. Disponível em: http://www.planalto.gov.br/ccivil_03/leis/19394.htm . Acesso em: 03 jun. 2020.

BRASIL. PRESIDÊNCIA DA REPÚBLICA. Constituição da República Federativa do Brasil de 1988. Disponível em: http://www.planalto.gov.br/ccivil_03/constituicao/constituicao.htm. Acesso em: 03 jun. 2020.

BRASIL. PRESIDÊNCIA DA REPÚBLICA. Constituição Política do Império do Brasil, elaborada por um Conselho de Estado e outorgada pelo Imperador D. Pedro I, em 25.03.1824. Disponível em http://www.planalto.gov.br/ccivil_03/Constituicao/Constituicao24.htm . Acesso em: 03 jun. 2020.

BRASIL, PRESIDÊNCIA DA REPÚBLICA. Decreto $n^{o} 119$ - $a$, de 7 de janeiro de 1890 . Prohibe a intervenção da autoridade federal e dos Estados federados em materia religiosa, consagra a plena liberdade de cultos, extingue o padroado e estabelece outras providencias. Disponível em: http://www.planalto.gov.br/ccivil_03/decreto/1851-1899/D119-A.htm. Acesso em: 03 de jun. de 2020.

BRASIL. CÂMARA DOS DEPUTADOS. Constituição dos Estados Unidos do Brasil, 1891. Disponível em: https://www2.camara.leg.br/legin/fed/consti/1824-1899/constituicao-3508124-fevereiro-1891-532699-publicacaooriginal-15017-pl.html . Acesso em: 15 maio 2020.

BRASIL. CÃMARA DOS DEPUTADOS. Decreto $n^{\circ}$ 7.107, de 11 de fevereiro de 2011. Disponível em: https://www2.camara.leg.br/legin/fed/decret/2010/decreto-7107-11-fevereiro2010-602309-publicacaooriginal-123632-pe.html . Acesso em: 10 jun. 2020.

CHARTIER, R. Prefácio. In: ELIAS, N. A sociedade de corte. p. 1-75. Rio de Janeiro: Zahar, 2001. [Publicação alemã base para tradução, 1983. Edição eletrônica. 2012]

DINES, A. Catequese na mídia contraria Estado laico. Observatório da Imprensa, 11 maio 2007. Disponível em: http://www.observatoriodaimprensa.com.br/e-noticias/catequese-damidia-contraria-estado-laico/ . Acesso em: 30 junho 2020.

DORNAS-FILHO, J. O Padroado e a Igreja Brasileira. Série 5a, Brasiliana, Vol. 125. São Paulo: Companhia Editora Nacional, 1938.

ELIAS, N. A sociedade de corte. Rio de Janeiro: Zahar, 2001. [Publicação alemã base para tradução, 1983. Edição eletrônica. 2012]

FISCHMANN, R. Ameaça ao Estado laico. Folha de S. Paulo, 14 nov. 2006. Disponível em: https://www1.folha.uol.com.br/fsp/cotidian/ff1411200622.htm . Acesso em: 10 jul. 2020. 
FISCHMANN, R. A imprensa em falta com o Brasil. Observatório da Imprensa, 8 maio 2007 (2007-a). Disponível em: http://www.observatoriodaimprensa.com.br/diretorio-academico/aimprensa-em-falta-com-o-brasil/ . Acesso em: 10 jul. 2020.

FISCHMANN, R. Lula e o Estado laico. Folha de S. Paulo, 15 maio 2007, p. 1-3 (2007-b). Disponível em: https://www1.folha.uol.com.br/fsp/opiniao/fz1505200709.htm. Acesso em: 10 jul. 2020.

FISCHMANN, R. A omissão da mídia sobre o Acordo com o Vaticano. Observatório da Imprensa, 18 novembro 2008.2 Disponível http://www.observatoriodaimprensa.com.br/interesse-publico/omissao-da-midia-sobre-oacordo-com-o-vaticano/ . Acesso em 20 jun. 2020.

FISCHMANN, R. A proposta de concordata com a Santa Sé e o debate na Câmara Federal. Educação e Sociedade, Campinas, vol. 30, n. 107, p. 563-583, maio/ago. 2009. Disponível em: http://www.scielo.br/pdf/es/v30n107/13.pdf . Acesso em: 03 de jun. 2020.

FISCHMANN, R.. Educação laica (nas escolas públicas): Uma questão política, cultural e de direito. International Studies on Law and Education, 11 mai-ago 2012, p.5-18. CEMOrOcFeusp / IJI-Univ. do Porto. Disponível em: http://www.hottopos.com/isle11/05-18Roseli.pdf . Acesso em: 03 jun. 2020.

GONDRA, J. Sem Deus nem Rei? O positivismo na escrita da educação brasileira. Revista Brasileira de Estudos Pedagógicos, v. 77 n. 185 (1996). Disponível em: http://www.rbep.inep.gov.br/ojs3/index.php/rbep/article/view/1196 . Acesso em: 15 jun. 2020.

PORTAL G1. Lula encontra Papa Bento XVI no Vaticano. Matéria publicada online em 13 nov. 2008. Disponível em: http://g1.globo.com/Noticias/Politica/0,,MUL860754-5601,00LULA+ENCONTRA+PAPA+BENTO+XVI+NO+VATICANO.html. Acesso em: $10 \mathrm{jul}$. 2020.

SANTOS, G. A.; TORRES, M. A.; FONSECA, M. V.. A invisibilidade de crenças não cristãs na formação de professores de ensino religioso em Ouro Preto e Mariana. Escritas. Vol. 8 n. 1 (2016) ISSN 2238-7188 p. 23-41.

XAVIER, D.; LOREA, R.; FISCHMANN, R. Brasil e Vaticano: o (des)acordo republicano. Brasília. CFÊMEA, 2009. Disponível em: https://www.cfemea.org.br/index.php/colecaofemea-e-publicacoes/publicacoes/4333-brasil-e-vaticano-o-desacordo-republicano * Acesso em: 10 jun. 2020.

WACHOLTZ, W. Identidades forjadas na interdependência: o caso católico e protestante no Brasil do século XIX. Revista Mosaico, v.2, n.2, p.117-124, jul./dez., 2009. Disponível em: http://seer.pucgoias.edu.br/index.php/mosaico/article/viewFile/969/677. Acesso em: 20 jun. 2020.

\footnotetext{
${ }^{\mathrm{i}}$ Ver, a respeito do Padroado, DORNAS-FILHO, 1938.

ii É vasta a produção acadêmica sobre o Positivismo, a Educação e a Ciência no Brasil. Ver, por exemplo, GONDRA, 1996, entre outros.

iii São tantos nomes que estão firmes na atual luta, que citá-los seria necessariamente parcial e por isso impróprio.
} 